\title{
EFFECT OF WASTEWATER AND FERTILIZER APPLICATION ON CALCAREOUS SOIL AND FOOD CROPS IN BORG EL ARAB - EGYPT
}

\author{
S.A.E. Abdelrazek and R.I. Fayed \\ Soil Salinity and Alkalinity Department, Alexandria, Soil, Water and Environment \\ Research Institute, Agriculture Research Center, Giza, Egypt \\ Email: Samad_saad@yahoo.com
}

Received: Aug. 14, 2018

Accepted: Sep. 16, 2018

\begin{abstract}
This paper summarizes the available information on the pollution of groundwater and irrigation canals from anthropogenic sources (sewage effluences and industrial waste water, and intensive fertilization) in northwestern Egypt Borg El Arab that leading to contamination of the soil-plant-animal. Excessive applications of fertilizers to field and vegetable crops lead to nitrate and phosphate contamination of groundwater and irrigation canals. In certain situations, nitrates exceed the dangerous level of $10 \mathrm{mg} \mathrm{N} / \mathrm{L}$. Industrial effluents, released without any treatment to sewage drains, contain potentially toxic elements with a concentrations that are several fold higher than those in domestic sewage water and exceed the maximum permissible limits for their disposal onto agricultural lands. The mean concentrations of $\mathrm{Pb}, \mathrm{Co}, \mathrm{Cd}$ and $\mathrm{Ni}$ in sewage water were, respectively 21,133, 700, and 2200 times higher than those in artesian water. The recommendation possible mitigation options for water pollution. There is an urgent need to effectively enforce regulations for the release of industrial effluents pertaining to primary, secondary and tertiary treatments. Educating farmers and public at large about the consequences of non-overkill Nitrogen fertilizer, pumping out shallow polluted water for drinking and domestic purposes, depleting groundwater resources, etc., is desirable
\end{abstract}

Key words: Groundwater pollution, Borg EI Arab, Irrigation water quality, Anthropogenic, contamination, nitrate, phosphate, cadmium, lead, cobalt, nickel

\section{INTRODUCTION}

Worldwide efforts have increasingly been focused on environmental pollution and its hazardous ill effects on humans and animals. The agricultural sector is the major consumer of water. In Egypt, agriculture accounts for $89 \%$ of total water use, as against $8 \%$ by domestic sector and $3 \%$ by industrial sector (CAPMAS, 2014).

Rapid industrialization and urbanization during the past few decades have increased the demand for available water and put stress on the already dwindling water resources. In northwestern Egypt in new reclaimed soils which constitute the subtropical region, the expansion of irrigation facilities has supported 2-3 crops annually, and new reclaimed soils region is regarded as the 'food basket of the country. However, the groundwater is depleting at a fast rate because of its excessive use and mismanagement (Shata et al., 1969).

Nitrate leaching into groundwater, $P$ movement into surface water and groundwater in soil can be associated with inefficient or excessive application of fertilizers and manures (Elsokkary, 1980).

The most important anthropogenic factor responsible for groundwater 
pollution is urban and industrial wastewater. Direct release of untreated effluents to land and irrigation canals can potentially contaminate surface and groundwater as well as soils and eventually the crops grown on these soils which affect the quality of the food produced (Aisueni et al., 2009).

This paper synthesizes the results of several studies conducted to investigate the impact of agricultural, urban and industrial activities on water pollution, which lead to contamination of the soilplant-animal-human food chain, and explore possible options for mitigating water pollution (Abdel-Migeed et al., 2007).

\section{MATERIALS AND METHODS}

\section{Location of the research areas}

The studied area is a part of the eastern section of the north - western costal region of Egypt. It was selected at Borg El Arab, 48 Kilometer west of Alexandria - Marsa Matruh road. It lays approximately between latitudes $30^{\circ} 45$ and $30^{\circ} 55 \mathrm{~N}$, and longitudes $29^{\circ} 30$ and $2950 \mathrm{E}$ The study area cover about 5000 feedan Map and has differences in elevation and relief. The elevation varies between zero and more than $40 \mathrm{~m}$. above sea level Fig (1).

\section{Soil and sewage sludge properties}

The soil was used a loamy clay (calcareous) taken from the surface layer of Borg El Arab - Alexandria Governorate. The sludge was the activated type and was municipal sewage sludge. The soil and sludge samples were air dried and crushed so as to pass a $2 \mathrm{~mm}$ sieve.

\section{Nitrate-N}

Regarding plant analysis, plant samples were oven dried at $60^{\circ} \mathrm{C}$ to preserve nitrogenous compounds and ground. A sample was wet-digested by Kjeldahl method according to Jackson, (1973) using sulfuric acid and hydrogen peroxide to determine $\mathrm{N}$. Nitrogen was measured by titration of ammonia against standard $\mathrm{HCl}$.

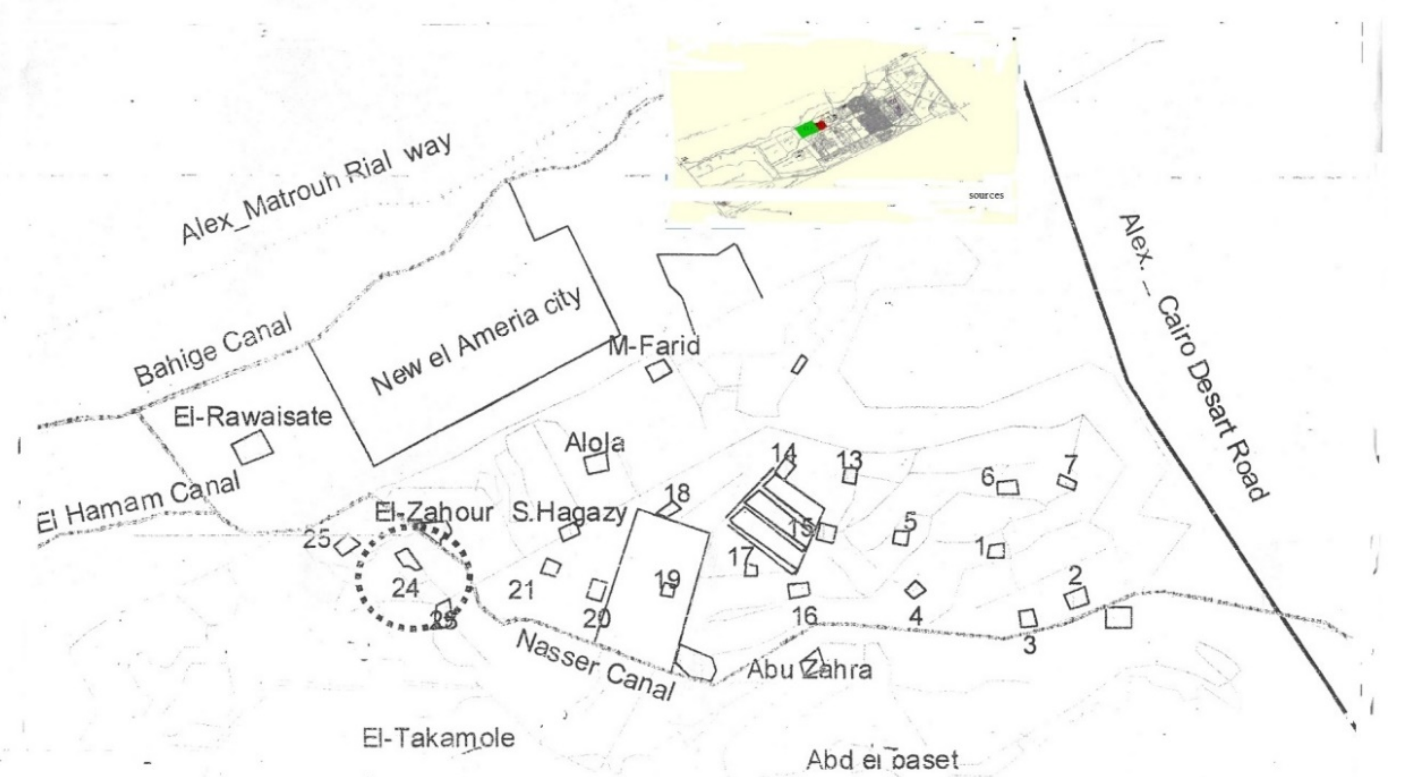

Location of studied area at Burg-Er-Arab sector

Figure (1): location of the research from the polluted sources in Borg El Arab 


\section{Olsen-P}

Available $P$ was determined according to (Olsen et al., 1965) and the $P$ content determined by the Murphy and Riley method (Murphy and Riley, 1962).

pH

$\mathrm{pH}$ and Ec were measured in a 1:2.5 water extract (Richards, 1954) lime was determined according to (Richards, 1954).

\section{Concentration of toxic elements (mg/L)}

Soil sample were extracted for available $\mathrm{Fe}, \mathrm{Zn}, \mathrm{Pb}, \mathrm{Ni}, \mathrm{Cd}$ and $\mathrm{Co}$ in DTPA solution $(0.005 \mathrm{M}$ DTPA $+0.005 \mathrm{M}$ $\mathrm{CaCl}_{2}+0.1 \mathrm{M}$ TEA (triethanolamine) $\mathrm{pH}$ (7.3), (Lindsay and Norvell, 1978). All the solutions of $\mathrm{Fe}, \mathrm{Zn}, \mathrm{Pb}, \mathrm{Ni}, \mathrm{Cd}$ and $\mathrm{Co}$ were analyzed by atomic absorption spectrophotometer.

\section{Statistical analysis}

Regression analysis and correlation coefficient were recruited to verify the relationship between the different variable responses that were measured in this work according to Gomez and Gomez, (1984).

\section{RESULTS AND DISCUSSION Agricultural activities}

Increased use of fertilizers in farming because of large-scale adoption of highyielding, fertilizer-responsive crops and varieties has led to a gradual buildup of nutrients in soil and groundwater. Movement of $\mathrm{N}$ and $\mathrm{P}$ below the root zone and leaching into the groundwater can cause human and animal health problems.

If the drinking water has more than the safe limit of $10 \mathrm{mg} \mathrm{NO}{ }^{-} \mathrm{N} / \mathrm{L}$, ingested nitrate is converted to nitrite that is absorbed in blood, causing methemoglobinemia, commonly known as 'Blue Baby Syndrome', and gastric cancer (Abdelrazek, 2017).

There are reports of eutrophication of irrigation canals due to both high nitrate and phosphate concentration. The concentrations of $P$ that cause eutrophication range from 0.01 to 0.03 mg/L (Khadr et al., 2004)

\section{Nitrogen}

High rates of leaching and denitrification in permeable or porous soils and relatively high fertilizer $\mathrm{N}$ rates combine to make nitrate-leaching a serious problem in many irrigated soils (Youness, 2002).

Intensively cultivated semiarid
subtropical region of Egypt where
average fertilizer $\mathrm{N}$ consumption
increased from 56 to $188 \mathrm{~kg} \mathrm{~N} /$ feedan/y
during 2015 to $2017, \mathrm{NO}_{3}^{--} \mathrm{N}$
concentration in the shallow-well waters
increased by almost $2 \mathrm{mg} / \mathrm{L}$.

In some central districts said darwiesh village in Borg EI Arab region, fertilizer $\mathrm{N}$ levels exceed $250 \mathrm{~kg} \mathrm{~N} /$ feedan /y and on several farms, fertilizers are poorly managed. The soils in this region are predominantly fine textured and about $\mathbf{7 5 \%}$ of the total rainfall of more than 200 $\mathrm{mm}$ is received during the winter period (November -February). A survey of groundwater samples from 25-100 meterdeep tube wells located in cultivated fields in various blocks revealed that $78 \%$ water samples had less than $5 \mathrm{mg} \mathrm{NO}{ }_{3}^{--}$ $\mathrm{N} / \mathrm{L}$ and $22 \%$ samples had 5-10 $\mathrm{mg} \mathrm{NO}_{3}{ }^{--}$ N/L. Sixty percent of water samples from shallow-depth (11-19 m) Artesian water had 5-10 $\mathrm{mg} \mathrm{NO} 3^{--} \mathrm{N} / \mathrm{L}$ and $2 \%$ samples had more than $10 \mathrm{mg} \mathrm{NO}_{3}{ }^{-\mathrm{N}} / \mathrm{L}$. excessive use , mismanagement and overkill Nitrogen fertilizer (Nitro) appear to be the major contributors to high $\mathrm{NO}_{3}^{--} \mathrm{N}$ in groundwater. Vegetation retards $\mathrm{NO}_{3}{ }^{-\cdots} \mathrm{N}$ leaching from the root zone by absorbing nitrate and water. 
Rooting habits/patterns of different plants influence $\mathrm{NO}_{3}{ }^{-}$mobility in the rooting zone. Maximum leaching of $\mathrm{NO}_{3}^{--}$ $\mathrm{N}$ below the root zone occurs from heavily fertilized shallow-rooted crops, such as potato, maize and Tomato as well as heavily manures vegetable crops. In the predominant Tomato-wheat cropping system of Borg El Arab $\mathrm{NO}_{3}{ }^{-}$ leaching to $40 \mathrm{~cm}$ during the Tomato crop was used by the subsequent wheat crop, which has a deeper and more extensive root system (Figure 2).

Application of $120 \mathrm{~kg}$ fertilizer $\mathrm{N} / \mathrm{feedan}$ to each of these two crops for 4 years resulted in $35 \mathrm{~kg}$ of residual $\mathrm{NO}_{3}{ }^{--}$ $\mathrm{N} /$ feedan in the $150-\mathrm{cm}$ soil profile, whereas only $17 \mathrm{~kg} \mathrm{NO}{ }^{--} \mathrm{N} /$ feedan remained where $120 \mathrm{~kg} \mathrm{~N} / \mathrm{ha}$ was applied through the consecutive use of $20 \mathrm{t} /$ feedan of fresh Alfalfa green manure and fertilizer $N$, decreasing potential for groundwater nitrate contamination

\section{Phosphorus}

Excessive accumulation of residual $P$ in soil may enhance downward movement of $P$, which may eventually reach groundwater.

Calcareous soils have a large number of macropores and thus the resultant by- pass flow can lead to greater and deeper leaching of $P$ in such soils.

Besides the Tomato and wheat crops for groundwater contamination, $P$ lost from agricultural soils through leaching may be intercepted by artificial drainage or subsurface flow, accelerating the risk of $P$ transport to irrigation canals with serious implications for water quality (Hartikainen, 1991). Long-term studies, where fertilizer $P$ has been applied at different rates, frequencies and periods, have revealed the possibility of $P$ leaching especially in coarse textured soils (Jalali and Ranjbar 2010) After 2 years of using Tomato and wheat crops based cropping systems, 45 to $256 \mathrm{~kg}$ of residual fertilizer $P$ accumulated as Olsen-P/ha in $150-\mathrm{cm}$ soil profile $(43-58 \%$ below $60 \mathrm{~cm}$ depth), illustrating enormous movement of fertilizer $P$ to deeper layers in a coarse-textured soil having low absorption and retention capacity for nutrients (Table 1). Recent studies with different cropping systems have further revealed that interplay between the fertilizer $P$ management, amount of labile $P$ accumulated in soil profile, and soil characteristics (silt, clay and organic $C$ ) largely control $P$ leaching in subtropical soils (Agbenin, and Goladi 1997).

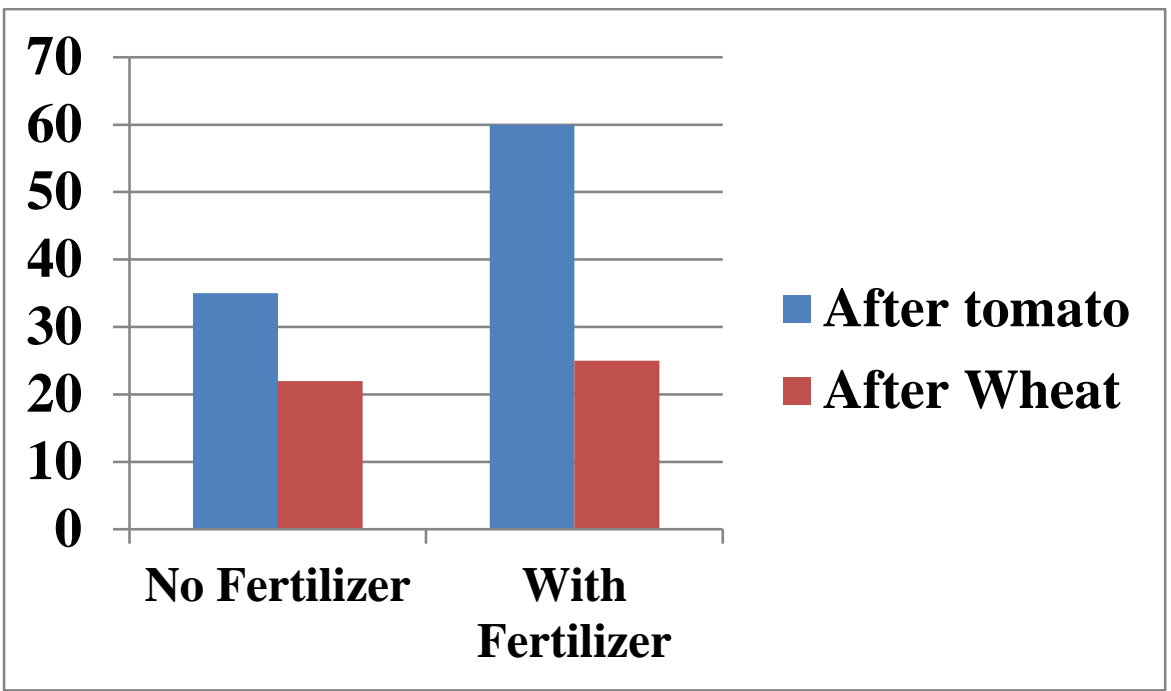

Figure (2): Nitrate- $\mathrm{N}$ in $60 \mathrm{~cm}$ soil profile after 2-years of Tomato and wheat crops 
Table (1). Olsen-P accumulation and leaching in soil profiles of no-P control and four fertilizer $P$ treatments after 2-years of Tomato and wheat crops - based cropping systems

\begin{tabular}{|c|c|}
\hline Soil depth(cm) & Olsen-P(mg P kg $\left.{ }^{-1}\right)$ \\
\hline \multicolumn{2}{|c|}{ control } \\
\hline 4 & 5 \\
\hline 25 & 7 \\
\hline 45 & 8 \\
\hline 70 & 8 \\
\hline 110 & 10 \\
\hline 130 & 10 \\
\hline \multicolumn{2}{|c|}{ Winter-applied P1 } \\
\hline 3 & 9 \\
\hline 26 & 8 \\
\hline 45 & 3 \\
\hline 70 & 3 \\
\hline 110 & 13 \\
\hline 140 & 14 \\
\hline \multicolumn{2}{|c|}{ Winter-applied P2 } \\
\hline 2 & 14 \\
\hline 30 & 14 \\
\hline 50 & 12.5 \\
\hline 80 & 11 \\
\hline 115 & 14 \\
\hline 125 & 14 \\
\hline \multicolumn{2}{|c|}{ Cumulative-applied P1 } \\
\hline 2 & 14 \\
\hline 30 & 15 \\
\hline 45 & 12.5 \\
\hline 72 & 7.5 \\
\hline 110 & 11 \\
\hline 135 & 11 \\
\hline \multicolumn{2}{|c|}{ Cumulative-applied P2 } \\
\hline 2 & 20 \\
\hline 15 & 20 \\
\hline 50 & 20 \\
\hline 73 & 15 \\
\hline 115 & 17.5 \\
\hline 145 & 20 \\
\hline
\end{tabular}




\section{Urban and industrial activities}

Application of sewage sludge to agricultural soils, and irrigation of field crops with sewage water and untreated industrial effluents alone, or in combination with ground/canal water are common practices, especially in the vicinity of large cities, as these are considered reusable sources of essential plant nutrients and organic $C$. It is estimated that more than 11000 million liters of sewage water is produced every day in Egypt which approximately contributes 3.2 million $t$ of $\mathrm{N}, 1.4$ million $t$ of $P$ and 1.9 million $t$ of potassium $(K)$ per annual with an economic value of about Egyptian EP 884 million (US\$ 52 million). However, some of the elements present in sewage water and untreated industrial effluents could be toxic to plants and pose health hazards to animals and humans (Abdelrazek, 2017).

\section{Chemical composition of sewage waters}

The concentration of potentially toxic elements was higher in sewage water of industrial towns as compared with less or non-industrial towns (Abdelrazek , 2014).

Further, the composition of sewage water varies within a city. The domestic zone sewage contained relatively low amounts of toxic elements whereas the effluents from the electroplating area contained toxic elements, such as cadmium (Cd), nickel (Ni) and cobalt (Co), in amounts higher than maximal tolerable limits for disposal on agricultural lands

The chemical analysis of sewagewater samples collected from different locations of an open drain, commonly known as Borg El Arab Industrial area, Mary Mina area and El-Rawaisate area downstream from entry into, Bahig area revealed that the concentration of metals in the drain increases many folds as it passes through Bahig area (Table 2).

The mean concentrations of $\mathrm{Fe}, \mathrm{Zn}$, $\mathrm{Cd}, \mathrm{Pb}, \mathrm{Ni}$, and $\mathrm{Co}$ the sewage-water samples collected at the entry point, were $0.03,0.04,0.0050 .004,0.002$ and 0.001 $\mathrm{mg} / \mathrm{L}$, respectively, which increased to $10.8,0.78,2.10,0.075,0.28$ and $0.26 \mathrm{mg} / \mathrm{L}$, respectively, in the samples collected from about $15 \mathrm{~km}$ downstream of the entry point. This is because the number of industries pouring their untreated effluents increased as the distance downstream increased turning it into a highly polluted sewage channel.

A study of industrial complex in Borg EI Arab city, comprising leather (Zakhary Company manufacturing factories, Ceramics (Lecico company) and faience factories, revealed that the concentration of both Co and Ni drastically increased in the sewage water after the disposal of effluents from the industrial complex (ElGendi et al., 1997: Abdel-Sabur et al., 1995).

The concentration of both the elements at $200 \mathrm{~m}$ from the polluted source of the leather complex increased many fold as compared with that from $500 \mathrm{~m}$ upstream, indicating the high pollution potential of these elements. However, the concentration of Co decreased $2 \mathrm{~km}$ from the polluted source of the industrial complex because of settling of some of the elements at the base of the drain.

Table (2). Concentration of toxic elements $(\mathrm{mg} / \mathrm{L})$ and $\mathrm{pH}$ of the effluents in Borg El Arab

\begin{tabular}{|l|c|c|c|c|c|c|c|}
\hline Sampling sites & $\mathrm{pH}$ & $\mathrm{Fe}$ & $\mathrm{Zn}$ & $\mathrm{Pb}$ & $\mathrm{Ni}$ & $\mathrm{Cd}$ & $\mathrm{Co}$ \\
\hline Entry point & 8.3 & 0.40 & 0.05 & 0.005 & 0.003 & 0.004 & 0.07 \\
\hline 2 km from sources & 7.6 & 6.8 & 0.19 & 0.080 & 0.23 & 0.180 & 1.70 \\
\hline $15 \mathrm{~km}$ from sources & 7.1 & 11.7 & 0.69 & 0.076 & 0.39 & 0.280 & 2.30 \\
\hline
\end{tabular}




\section{Effects of polluted water on soil}

It has well been documented that irrigation with sewage water increases soil electrical conductivity and organic C, decreases soil $\mathrm{pH}$, and could result in the accumulation of heavy metals in the plow layer of agricultural soils.

Ahmed, (2001) found that mean concentrations of DTPA-extractable $\mathrm{Pb}$, $\mathrm{Ni}, \mathrm{Cd}, \mathrm{Zn}, \mathrm{Mn}$ and $\mathrm{Fe}$ in surface soils (0$15 \mathrm{~cm}$ ) surrounding the densely industrialized city in the Kafer El-Dawar industrial area.

Irrigated largely with sewage effluents, were $4.2,3.6,0.30,11.9,25.4$ and 49.2 $\mathrm{mg} / \mathrm{kg}$ as compared, with $2.8,0.40,0.12$, $2.1,8.3,10.9 \mathrm{mg} / \mathrm{kg}$, respectively, in the soils around a less industrialized city of Mary Mina area Indicating greater loading of soils of Bahig area with potentially toxic metals through sewage irrigation. In industrialized cities of Borg EI Arab Industrial area, Mary Mina area mean concentrations of these metals, except $\mathrm{Pb}$ and $\mathrm{Zn}$ in Borg El- Arab, were inbetween the values for Bahig area and Rawaisate area.

\section{Effects of polluted water on plants}

Plant species absorbed higher concentration of potentially toxic metals like $\mathrm{Pb}, \mathrm{Cu}, \mathrm{Co}, \mathrm{Cd}, \mathrm{Ni}, \mathrm{Zn}, \mathrm{Mn}$, and $\mathrm{Fe}$ in different plant parts when grown in sewage-irrigated soils, as compared with tubewell-irrigated soils. For example, the concentration of $\mathrm{Cd}$ in aboveground parts of maize (Zea mays L.), rapeseed Turnip (Brassica rapa.) and lady's finger (Abelmoschus esculentus L.) grown on polluted soils was 2.0-3.5 times the amount of $\mathrm{Cd}$ when grown on nonpolluted soils. The increase in $\mathrm{Ni}$ concentration in various crops with waste-water-irrigated crops was 16 to $136 \%$ higher than that in tubewellirrigated crops (Abu Zeid, 1991).

The roots of all the crops, with a few exceptions, accumulated higher amounts of potentially toxic elements than aboveground parts. Vegetables like spinach (Spinacea oleracea L.), cauliflower (Brassica oleracea L. var botrytis) and cabbage (Brassica oleracea L. var capitata) tended to accumulate relatively higher concentrations of potentially toxic elements as compared with cereal crop like maize. Among the four vegetables, spinach accumulated the highest amount of all the metals.

\section{Recommendations}

Possible mitigation options for water pollution

Contamination of groundwater and irrigation canals due to agricultural, urban and industrial activities poses a threat to ecosystem of Borg El Arab Industrial area.

Several studies are evidently (obviously) appeared that the dangers of groundwater pollution are genuine, and in some cases, the situation is alarming particularly overkill Nitrogen fertilizer (Nitro).

Excessive applications of fertilizers to some crops lead to augment the nitrate and phosphate leaching. Formulation and adoption of careful strategies for applying appropriate amounts of fertilizers and manures at proper times, using correct methods, should help synchronize nutrient supply with crop need and avoid excessive use in crops in turn, reduce nitrate and phosphate pollution of groundwater and irrigation canals.

Water-pollution potential in industrialized cities like Borg El Arab Industrial area, Mary Mina area is manyfolds higher as compared with non- or less-industrialized cities. Therefore, sewage-water of such cities can only be used safely for irrigation after proper treatment. Local bodies need to install effluent treatment plant and only treated 
waste water should be allowed to be disposed of in irrigation canals.

Efforts should be made to encourage the industries to install their own plants within some agreed time frame to become zero discharge industries. Since very high cost is involved in the installation of treatment plants, many industries cannot install their own treatment plants. Therefore new industries should be allotted plots in such a way that a cluster of identical industries are grouped together so that common treatment plants could be set up for effective treatment economically.

There is an urgent need to effectively enforce regulations for the release of industrial effluents pertaining to primary, secondary and tertiary treatments. Educating farmers and public at large about the consequences of non-overkill Nitrogen fertilizer, pumping out shallow polluted water for drinking and domestic purposes, depleting groundwater resources, etc., is desirable. Farm yard manure, calcium carbonate, phosphate, zinc and zeolites are suitable ameliorants for mitigating pollutant toxicity in soils. On the other hand some crops belonging to brassica (a plant of a genus that includes cabbage, turnip, Brussels sprout, and mustard), Species and aromatic grasses that accumulate to higher amounts of pollutants in the shoots and roots may be utilized. The hyper-accumulation capability of these crops could be exploited for phytoremediation of toxic elements from polluted soils. Growth of timber and floriculture crops and use of aquatic macrophytes and constructed wetlands need to test for the removal of toxic pollutants.

\section{REFERENCES}

Abdel-Migeed, M.M., M.M.S. Saleh and E.A.M. Mostafa (2007). The beneficial effect of minimizing mineral nitrogen fertilization on Washington navel orange tree by using organic and biofertilizer. World J. Agric. Sci., 3(1): 80-85.

Abdelrazek, A. E. (2014). Effect of Wastewater Irrigation on Plant Enzymes and Soil Health Assessment in Borg El Arab Region, PH.D A thesis University of Sadat City

Abdelrazek, A. E. (2017). Heavy metals risk assessment for potato (Solanum tuberosum L.) Grown in soils at Borg El Arab region - Egypt Alexandria Science Exchange Journal, 38 (3): 620-625.

Abdelrazek, A. E. (2017). Artesian water contamination with salinity and heavy metals at different distances at Borg El Arab, Alexandria - Egypt. Alexandria Science Exchange Journal, 37 (3): 716-721.

Abdel-Sabur, M. F., A. S. Ismail and H. Abou- Naga (1995). Environmental impact of Cairo sewage effluent in Elgabal-Elasfar of from Egypt. J. Soil Sci. 35: 225

Abu Zeid, M. (1991). Egypt Water Resources Management and Policies. In: Comprehensive Water Management Policy Workshop. The World Bank, Washington. D. C. Jun. 24-28.

Agbenin, J.O. and J.T. Goladi (1997). Carbon, nitrogen and phosphorus dynamics under continuous cultivation as influenced by farmyard manure and inorganic fertilizers in the savanna of northern Nigeria. Agriculture, Ecosystems and Environment. 63: 17-24

Ahmed, S.M. (2001). phytoremidiation of some contaminated water with heavy metals in the Kafer El-Dawar industrial area Ph.D. Thesis, Fac of Agric., Alexandria University, Egypt

Aisueni, N.O.O., C.E. Ikuenobe, E.C. Okolo and F. Ekhator (2009). Response of date palm (Phoenix dactylifra) seedling to organic manure, 
$N$ and $K$ fertilization in polybag nursery. African J. Agric. Res., 4:162165 Alexandria Science Exchange Journal, 41 (7): 162-165.

CAPMAS, (2014). Future of Energy in Egypt. Cairo, Egypt: Central Agency for Public Mobilization and Statistics (CAPMAS).

El-Gendi, S. A., S.H. Badawy and M.I.D. Helal (1997). Mobility of some heavy metal nutrients in sandy soils irrigated with sewage effluent. J. Agric. Sci. Mansoura Univ., 22: 3535

Elsokkary, I. H. (1980). Contamination of edible parts of seven plant crops and soils by heavy metals in urban areas by air pollution in Alexandria distract, Egypt, In Atmospheric Pollution. Proceeding of the $14^{\text {th }}$ Init Collogium, Paris, France, May 1980, M. M. Benarie (Ed), Studies in Environ. Sci. Elsevire Sci. Pul., pp. 431 -438.

Gomez, K.A. and A.A. Gomez (1984). Statistical procedures for agricultural Res. 2nd ed. Wiley, New York

Hartikainen, H. (1991). Potential mobility of accumulated phosphorus in soil as estimated by the indices of Q/I plots and by extractant. Soil Science 152: 204-209.

Jackson, M.L. (1973). Soil chemical analysis. Prentice Hall Inc. Eng. Cliffs. U.S.A.

Jalali, M. and F. Ranjbar (2010). Aging effects on phosphorus transformation rate and fractionation in some calcareous soils. Geoderma. 155: 101106.

Khadr, M.S., R. Abou-EL-Enein, A. Abd EL-Shafy, F.A. Zahran and A.A. Zohty (2004). Sustainability of soil fertility status after 3-year crop rotation in sandy soil in Egypt. Egypt. J. Agric. Res. 82(2): 475-491.

Lindsay, W.I. and W.A. Norwell (1978). Development of a DTPA soil test for $\mathrm{Zn}, \mathrm{Fe}, \mathrm{Mn}$, and $\mathrm{Cu}$. soil sci. Am. J. 42: 421-428.

Murphy, and Riley (1962). A modified single solution method for the determination of phosphate in natural waters. Anal. Chem. Acta, 27: 31-36.

Olsen, S.R., V. Cole, F.S. Watanabe and L.B. Dean (1965). Estimation of available phosphorus in soils by extraction with sodium bicarbonate. U.S. Dept. of Agr. 939. Washingt,D.C.

Richards, L.A., ed. (1954). Diagnosis and improvement of saline and alkali soils. U.S.D.A. Handbook 60.

Shata, A. and M. El- Fayoumi (1969). Geomorphological and morphological aspects of west Nile Delta with special reference to Wadi El- Natrun area. Bull. Inst. Desert., 36: 15:19

Youness, E. R. (2002). Effect of different sources and methods of nitrogen application on vegetative growth and fruiting of Valencia orange trees. Ph.D Thesis, Fac. Agric., Minia Univ. 
تأثير استخدام مياه الصرف الصحي والأسمدة على التربة الجيرية والمحاصيل الغذائية

$$
\text { بيرج العرب - مصر }
$$

سعد عبد الصمد السيد عبد الرازق - رجب اسماعيل فايد

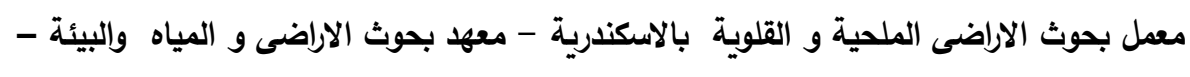

مركز البحوث الزراعية - الجيزة - مصر

الملخص العربى

تلخص هذه الورقة المعلومات المتاحة عن تلوث المياه الجوفية والمياه السطحية من المصادر البشرية في شمال

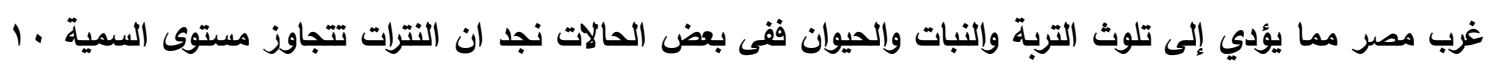

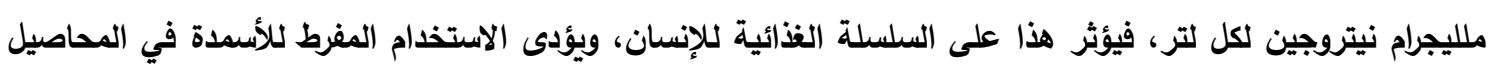

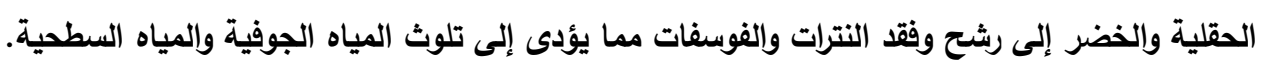

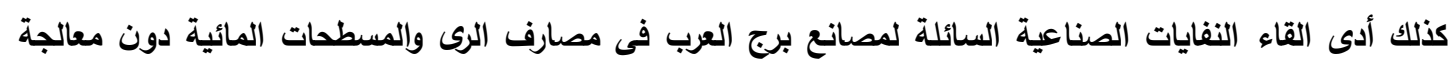

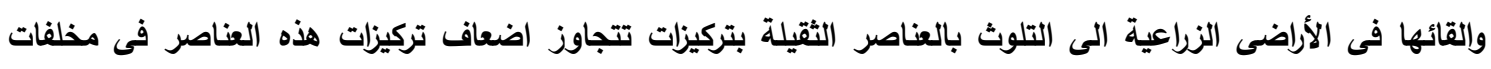
الصرف الصحى المنزلى وزيادتها عن للحدود القصوى المسموح بها. وقد وجد ان تركيزات الرصاص، والكوبل الكوبلت، والكادميوم

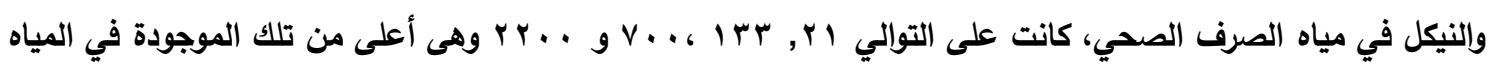

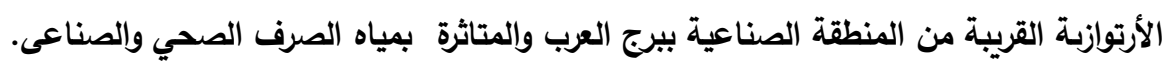

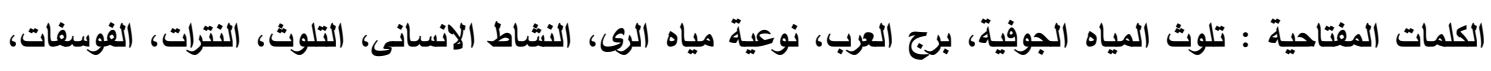
الكادميوم، الرصاص، الكوبالت، النيكل.

أسماء السادة المحكمين

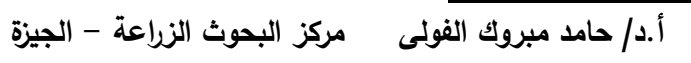

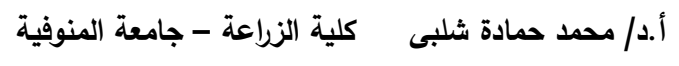


Effect of wastewater and fertilizer application on calcareous soil and .......... 